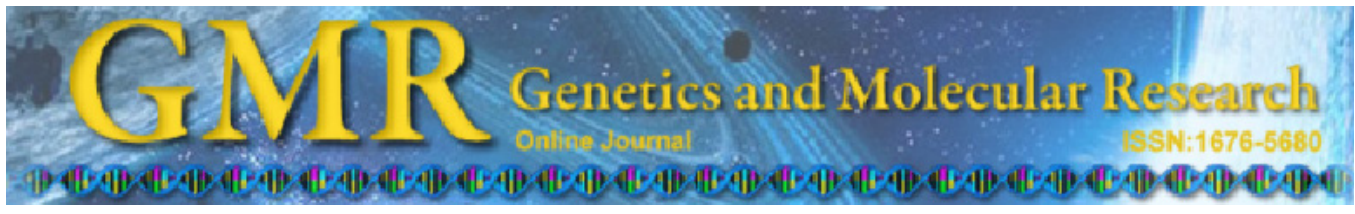

\title{
Assessment of genetic diversity of wheat genotypes by resistance gene analog-EST markers
}

\author{
O. Karakas ${ }^{1}$, F. Gurel ${ }^{2}$ and A.A. Uncuoglu ${ }^{3}$ \\ ${ }^{1}$ The Scientific and Technological Research Council of Turkey, \\ Marmara Research Center, Genetic Engineering and Biotechnology Institute, \\ Gebze-Kocaeli, Turkey \\ ${ }^{2}$ Department of Molecular Biology and Genetics, Istanbul University, \\ Istanbul, Turkey \\ ${ }^{3}$ Department of Bioengineering, Faculty of Engineering, Marmara University, \\ Goztepe, Istanbul, Turkey
}

Corresponding author: A.A. Uncuoglu

E-mail: ahu.uncuoglu@marmara.edu.tr

Genet. Mol. Res. 10 (2): 1098-1110 (2011)

Received September 15, 2010

Accepted November 26, 2010

Published June 14, 2011

DOI 10.4238/vol10-2gmr1065

ABSTRACT. Resistance gene analog-expressed sequence tag (RGA-EST)-based markers have been used for variety discrimination and studies of genetic diversity in wheat. Our aim is to increase the competitiveness of public wheat breeding programs through intensive use of modern selection technologies, mainly markerassisted selection. The genetic diversity of 77 wheat nucleotide binding site (NBS)-containing RGA-ESTs was assessed. Resistant and susceptible bread wheat (Triticum aestivum) genotypes were used as sources of DNA for PCR amplifications. In our previous studies, the $\mathrm{F}_{2}$ individuals derived from the combinations PI178383 x Harmankaya99, Izgi2001 x ES14, and Sonmez2001 x Aytin98 were evaluated for yellow rust resistance at both seedling and adult stages to identify DNA markers. We have now examined the genetic variability among the resistant and susceptible Turkish wheat cultivars for yellow rust disease and the mean genetic distance between the cultivars. The highest similarity was 0.500 between Harmankaya99 and Sonmez2001. The lowest similarity was 0.286 between Aytin98, 
PI178383 and Aytin98, ES14. A relatively high level (49.5\%) of polymorphism was observed with 77 RGA-EST primers across the six wheat genotypes, despite the fact that all of them were local cultivars from geographically close locations. RGA-EST sequences were compared by BlastX algorithms for amino acid sequences to determine the polymorphic categories among the combinations. BlastX analyses of six RGA-ESTs that gave polymorphic patterns for all combinations were NBS-LRR class RGA, NB-ARC domain containing protein, NBS-type resistance protein RGC5, NBS-LRR-S/ TPK stem rust resistance protein, and putative MLA1 proteins, while 38 RGA-EST gave a monomorphic pattern.

Key words: Triticum; Biodiversity; RGA-EST; Genetic diversity; Yellow rust

\section{INTRODUCTION}

Wheat (Triticum aestivum L.) is the most important human food crop, and production has to be increased significantly in the next decades. The allohexaploid wheat genome $(2 n=$ $6 \mathrm{x}=42$ ) is one of the largest among crop species with a haploid size of 16 billion bp (Bennett and Leitch, 1995), and wheat genetics and genome organization have been extensively studied by molecular markers (Ercan et al., 2010; Akfirat-Senturk et al., 2010; Karakas et al., 2010). Molecular markers have been widely used in genetic analyses, breeding studies and investigations of genetic diversity and the relationship between cultivated species and their wild parents, because they have several advantages as compared with morphological markers, including high polymorphism and independence from effects related to environmental conditions and the physiological stage of the plant (Bertini et al., 2006).

Polymerase chain reaction (PCR)-based molecular markers are easy to use and exhibit a high degree of polymorphism. Microsatellites (SSRs: simple sequence repeats) (Plaschke et al., 1995), restriction fragment length polymorphism (RFLP) (Nagaoka and Ogihara, 1997), amplified fragment length polymorphism (AFLP) (Gulbitti-Onarici et al., 2007), selective amplification of microsatellite polymorphic loci (SAMPL) (Altintas et al., 2008), random amplified polymorphic DNA (RAPD) (Asif et al., 2005), and expressed sequence tag (EST)-derived contigs and singletons (Karakas et al., 2010) have been widely used to characterize genetic diversity in wheat accessions. Besides these marker types, the resistance gene-analog polymorphism (RGAP) approach (Chen et al., 1998), which utilizes high-resolution electrophoresis and sensitive detection of PCR products amplified with primers based on conserved domains of plant resistance genes, has been used to identify molecular markers tightly linked to or co-segregating with disease resistance genes and also genetic diversity (Shi et al., 2001; Yan et al., 2003). Many plant resistance gene analogs (RGA) have been isolated and identified from different plant species. Linkage analysis has shown that these RGAs are distributed throughout the genome and exist in clusters (He et al., 2003). Some RGAs have been demonstrated to be linked with known R genes. Most characterized RGA-encoding proteins containing an LRR (leucine-rich repeat) motif appear to be grouped in clusters and colocalized with a known resistance gene (Geffroy et 
al., 1999). Many RGAs containing an LRR motif have been isolated from wheat (Qin et al., 2003). Yellow rust, triggered by the biotrophic fungus Puccinia striiformis f. sp. tritici, is a fungal disease of considerable importance in cereal production in Turkey and in other temperate cereal-growing areas (Akar et al., 2007). McFadden et al. (2006) analyzed wheat EST sequences separately to identify a representative set of RGA families. Sequences that showed greater than $70 \%$ DNA sequence identity over at least $200 \mathrm{bp}$ were considered to be members of the same family, and the 115 wheat ESTs were grouped into 77 RGA families. In this study, these 77 wheat nucleotide binding site (NBS)-containing RGA-ESTs were used to assess genetic diversity among the yellow rust-resistant and -susceptible Turkish wheat cultivars. The objective of the present study was to establish genetic relationships between six wheat accessions and to assess the existing genetic variation and the potential among the accessions to start new breeding programs.

\section{MATERIAL AND METHODS}

\section{Plant materials and DNA extraction}

Six homozygous bread wheat genotypes (three yellow rust-resistant cultivars: PI178383, Izgi2001, Sonmez2001, and three yellow rust-susceptible cultivars: Harmankaya99, ES14, Aytin98) were obtained from the Anatolian Agricultural Research Institute, Eskişehir, Turkey. Leaves from resistant and susceptible plants were used for total genomic DNA extraction using the miniprep method of Weining and Landridge (1991) modified by Song and Henry (1995).

\section{Disease assay}

The resistance of cultivars was tested in the greenhouse by applying uredospores. The infection type was recorded using the 0-9 scale (McNeal et al., 1971) treating 0-6 as low infection type and 7-9 as high infection type. The disease score of PI178383, Izgi2001, and Sonmez2001 was 0 while that of Harmankaya99, ES14, and Aytin98 was 8 in greenhouse assays (Ercan et al., 2010; Akfirat-Senturk et al., 2010). These assays confirm that the genotypes differ greatly in their resistance to yellow rust disease.

\section{Analysis of wheat RGA-ESTs}

RGA-ESTs from two divergent NBS regions of wheat sequences of the NBS-LRR class were chosen from the NCBI web site (http://www.ncbi.nlm.nih.gov) according to McFadden et al. (2006). These RGA-EST sequences were further processed for vector contamination at the http://www.ncbi.nlm.nih.gov/VecScreen/VecScreen.html web site and undesired vector fragments extracted from sequence lists. RGA-ESTs of T. aestivum were then subjected to Primer Premier 5.0 and Primer 3.0 programs for PCR primer designing (Table 1). A total of 77 RGA-EST-derived primers were screened against six wheat genotypes to assess genetic diversity (Figure 1). They were also queried using the BlastX algorithm of the Basic Alignment Search Tool (Altschul et al., 1990) to determine functional annotation of polymorphic categories among wheat genotypes. 


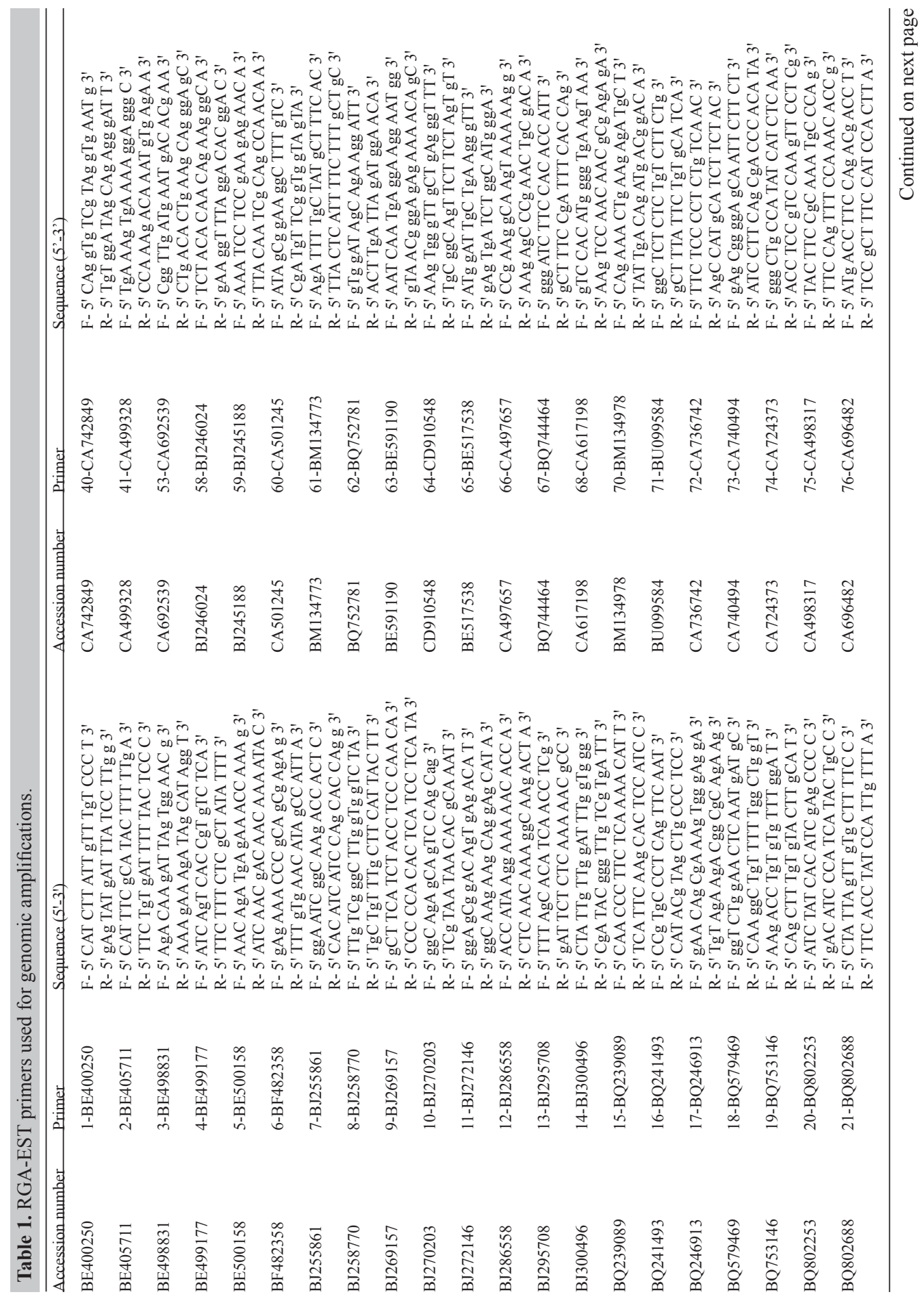




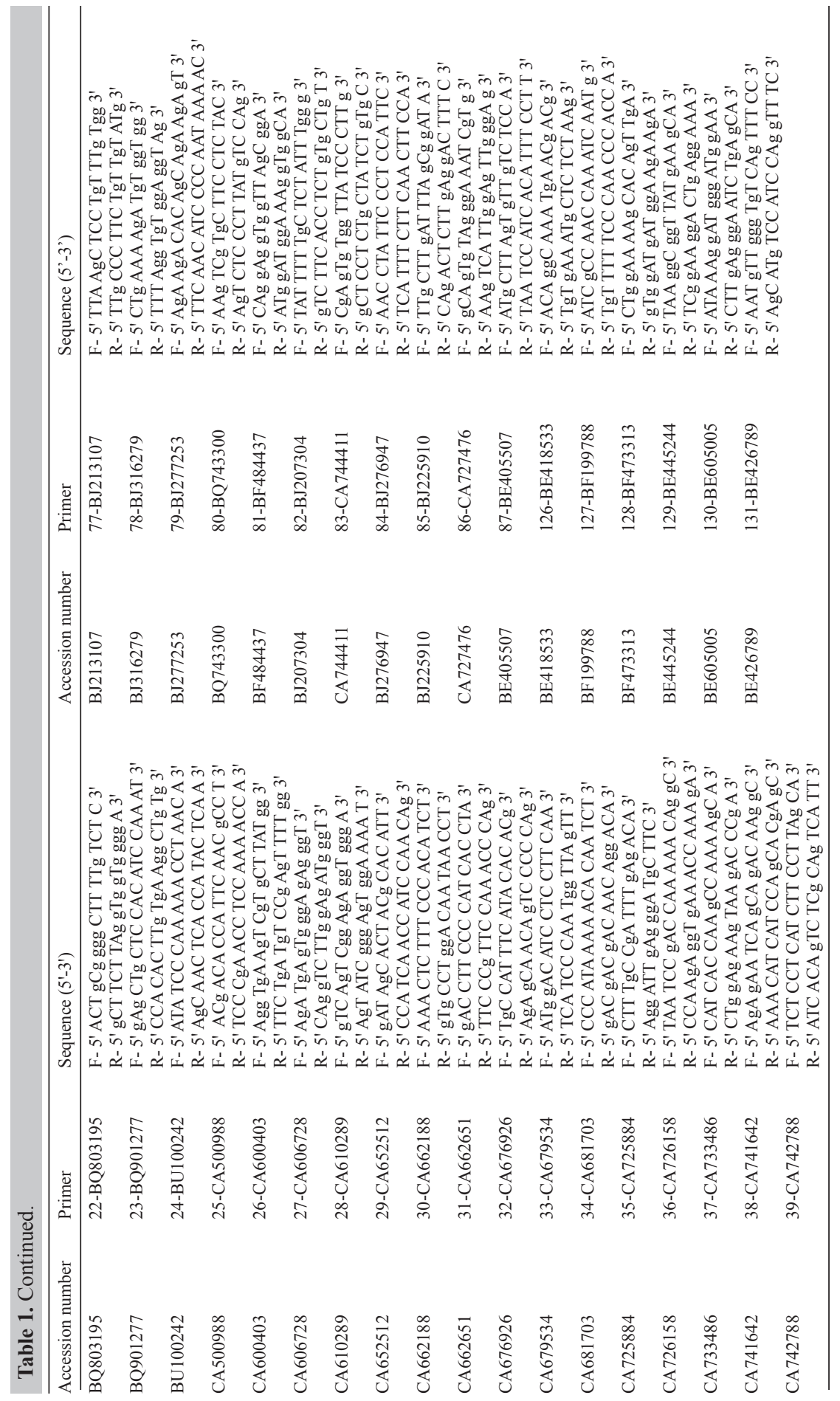



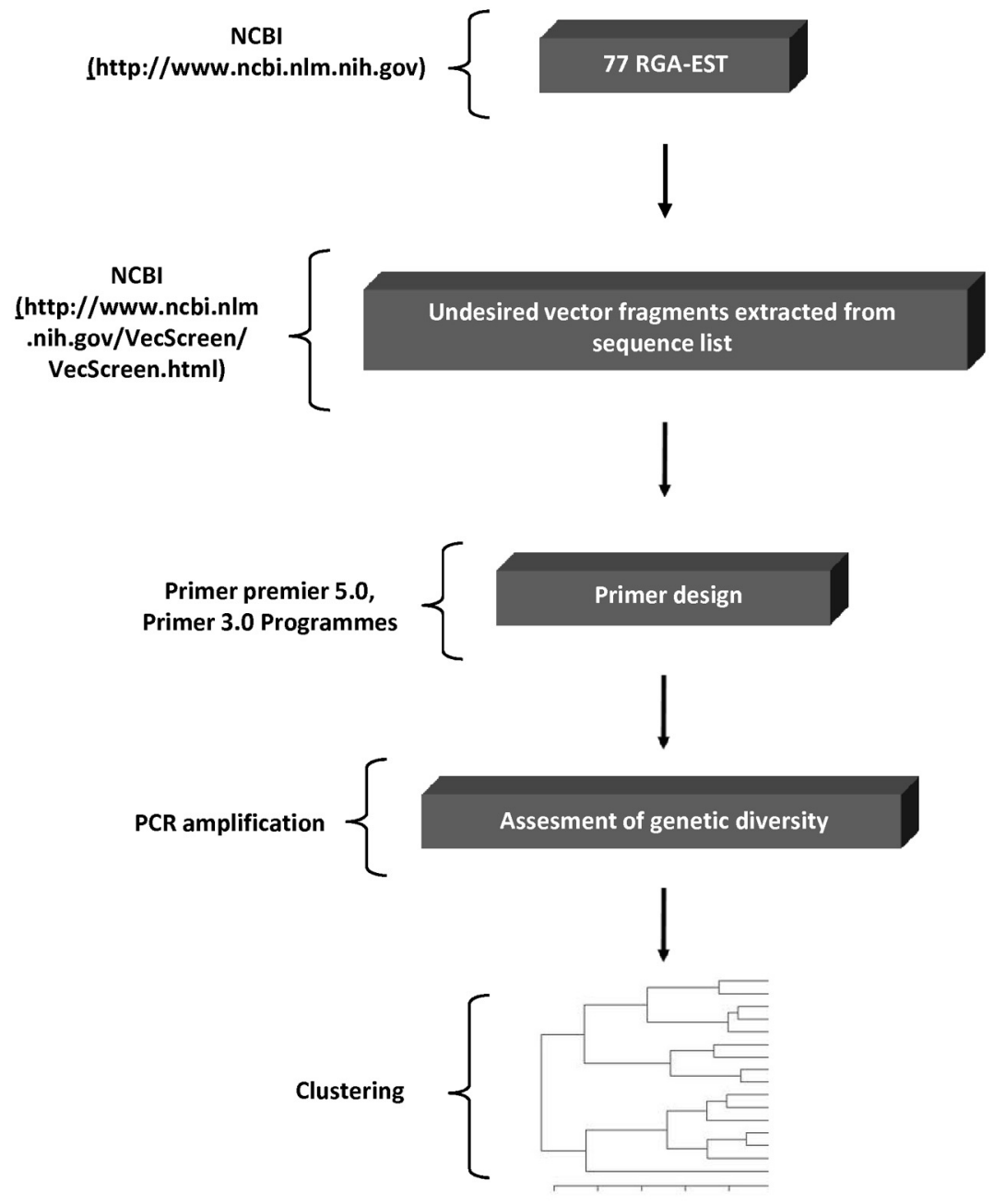

Figure 1. Schematic overview summarizing the strategy for using resistance gene analog-expressed sequence tags (RGA-ESTs) for assessment of genetic diversity.

\section{PCR amplification conditions}

Genomic DNA amplifications with the sense and antisense primers designed from RGA-ESTs specific for T. aestivum were performed using a PTC-100 MJ thermocycler (MJ Research, Watertown, MA, USA) in a $25 \mu \mathrm{L}$ reaction volume; each reaction contained $1 \mathrm{X}$ Taq buffer (MBI Fermentas, Germany), $2.5 \mathrm{mM} \mathrm{MgCl}_{2}$ (MBI Fermentas), $0.2 \mathrm{mM}$ dNTP (MBI Fermentas), $400 \mathrm{nM}$ forward primer, $400 \mathrm{nM}$ reverse primer ( $800 \mathrm{nmol}$ for RGA primers) and $0.625 \mathrm{U} / \mu \mathrm{L}$ Taq polymerase (MBI Fermentas) and $100 \mathrm{ng}$ genomic DNA. The thermal cycling parameters were $3 \mathrm{~min}$ at $94^{\circ} \mathrm{C}$ (initial denaturation), 37 cycles of $1 \mathrm{~min}$ at $94^{\circ} \mathrm{C}, 1 \mathrm{~min}$ at 50 $59^{\circ} \mathrm{C}$ (depending on annealing temperature) and $1 \mathrm{~min}$ at $72^{\circ} \mathrm{C}$, followed by a final extension 
at $72{ }^{\circ} \mathrm{C}$ for $10 \mathrm{~min}$. PCR amplification products were separated by electrophoresis on $2 \% \mathrm{TAE}$ agarose gels and stained with ethidium bromide for visualization.

\section{Assessment of genetic similarity}

Each RGA-EST band was scored as present (1) or absent (0) for the different cultivars and the data were entered into a binary matrix as discrete variables (' 1 ' for presence and ' 0 ' for absence of a homologous fragment). Only distinct, reproducible, well-resolved fragments were scored, and the data were analyzed using the MVSP 3.1 (Multivariate Statistical Package) program (Kovach, 1999). The MVSP software package version 3.1 was used to calculate Jaccard's (1908) similarity coefficients. Using these coefficients a dendrogram was constructed by the neighbor-joining algorithm.

\section{RESULTS}

\section{RGA-EST polymorphism and clustering}

Primers designed from RGA-EST sequences are useful for PCR-based discrimination between genotypes where differences between resistance and susceptibility are due to the presence of functional and nonfunctional R-gene homologues. A total of 77 primers were used to characterize the genetic diversity of six wheat genotypes, and 38 RGA-EST primers were polymorphic between susceptible and resistant wheat combinations. These combinations were created by crossing yellow rust tolerant (PI178383, Izgi2001 and Sonmez2001) and susceptible (Harmankaya99, ES14 and Aytin98) parents, respectively, in the wheat breeding program of the Anatolian Agricultural Research Institute. Interestingly, 6 RGA-EST primers (3-BE498831, 6-BF482358, 19-BQ753146, 34-CA681703, 35-CA725884, and 37-CA733486) of 38 gave polymorphic pattern for all combinations. The BlastX homolog of the sequences, which are the source for primer designing, was related to the NBS regions of wheat sequences. The rest of the 38 RGA-EST primers were monomorphic and only one of the RGA-EST primers (84BJ276947) gave no amplifications in all genotypes (Figure 2). Pairwise similarity within groups, obtained by MVSP 3.1, varied from 0 to 0.500 and is summarized in Table 2 . The highest similarity was 0.500 between Harmankaya99 and Sonmez2001. The lowest similarity was 0.286 between Aytin98, PI178383 and Aytin98, ES14. The dendrogram produced two main clusters, the first included the wheat cultivar Aytin98 and Izgi2001, the second main cluster was divided into two subclusters. The first subcluster comprised only PI178383. The second subcluster was also divided into two subclusters. One of them included only ES14, and the other one included Sonmez2001 and Harmankaya99. Similarity index (Jaccard's coefficient) of the tested cultivars resulting in a dendrogram presented in Figure 3, demonstrates the ability of RGA-EST to detect large amounts of genetic diversity in genotypes with expected narrow genetic pool.

A total of 77 wheat NBS-containing RGA-ESTs were compared by BlastX algorithms in the NCBI for amino acid sequences. BlastX analysis of these sequences (BE498831, BF482358, BQ753146, CA681703, CA725884, and CA733486), gave a polymorphic pattern for all combinations, and they were NBS-LRR class RGA, NB-ARC domain containing protein, NBS-type resistance protein RGC5, NBS-LRR-S/TPK stem rust resistance protein, and putative MLA1 proteins (Figure 4), while 38 RGA-EST primers produced a monomorphic 


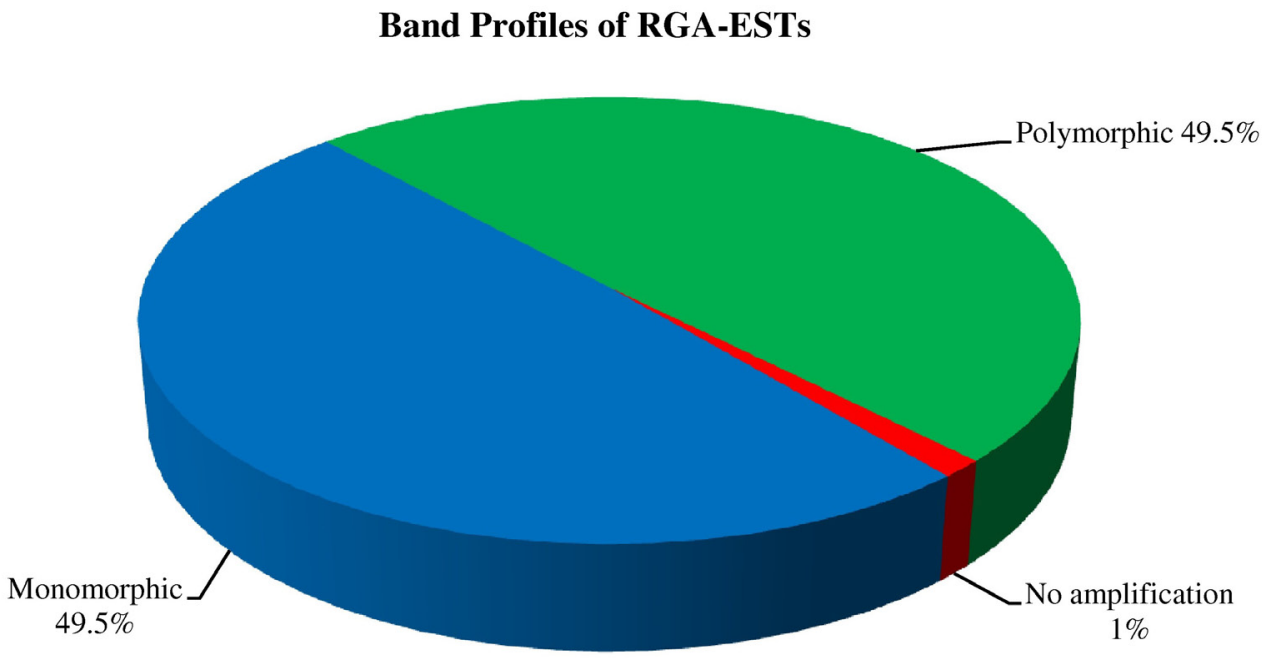

Figure 2. Schematic representation for the band profiles of resistance gene analog-expressed sequence tags (RGA-ESTs).

Table 2. Similarity index (Jaccard's coefficient) between cultivars of Triticum aestivum.

\begin{tabular}{|c|c|c|c|c|c|c|}
\hline Pop. ID & PI178383 & Izgi2001 & Sonmez2001 & Harmankaya99 & ES14 & Aytin98 \\
\hline PI178383 & $* * * *$ & & & & & \\
\hline Izgi2001 & $0.292^{\dagger}$ & $* * * *$ & & & & \\
\hline Sonmez2001 & $0.344^{\dagger}$ & $0.373^{\dagger}$ & $* * * *$ & & & \\
\hline Harmankaya99 & $0.393^{\dagger}$ & $0.379^{\dagger}$ & $0.500^{\dagger}$ & $* * * *$ & & \\
\hline ES14 & $0.393^{\dagger}$ & $0.333^{\dagger}$ & $0.410^{\dagger}$ & $0.417^{\dagger}$ & $* * * *$ & \\
\hline Aytin98 & $0.286^{\dagger}$ & $0.426^{\dagger}$ & $0.435^{\dagger}$ & $0.333^{\dagger}$ & $0.286^{\dagger}$ & $* * * *$ \\
\hline
\end{tabular}

$\dagger=$ genetic similarity.

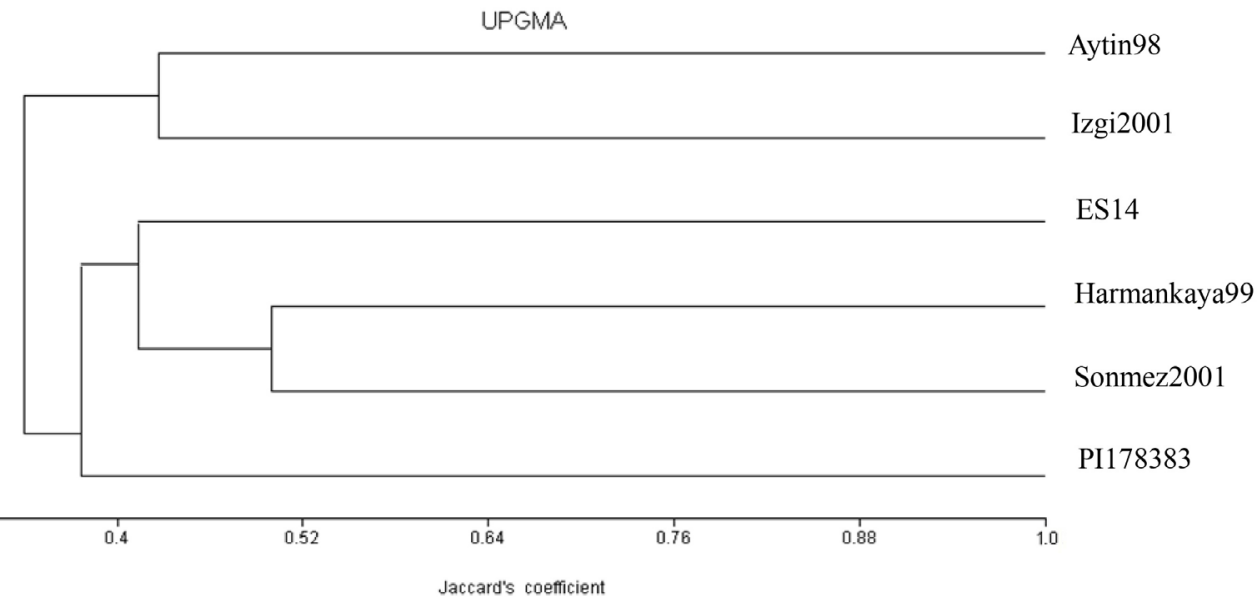

Figure 3. Genetic similarity relationships based on Jaccard's similarity coefficients after cluster analysis of bread wheat (Triticum aestivum L.) accessions from Turkey using RGA-EST markers. 
pattern, and also the BlastX searches revealed that the blast hit homolog of the RGA-EST sequences match various organisms, such as Oryza, Hordeum, Sorghum (Figure 5).

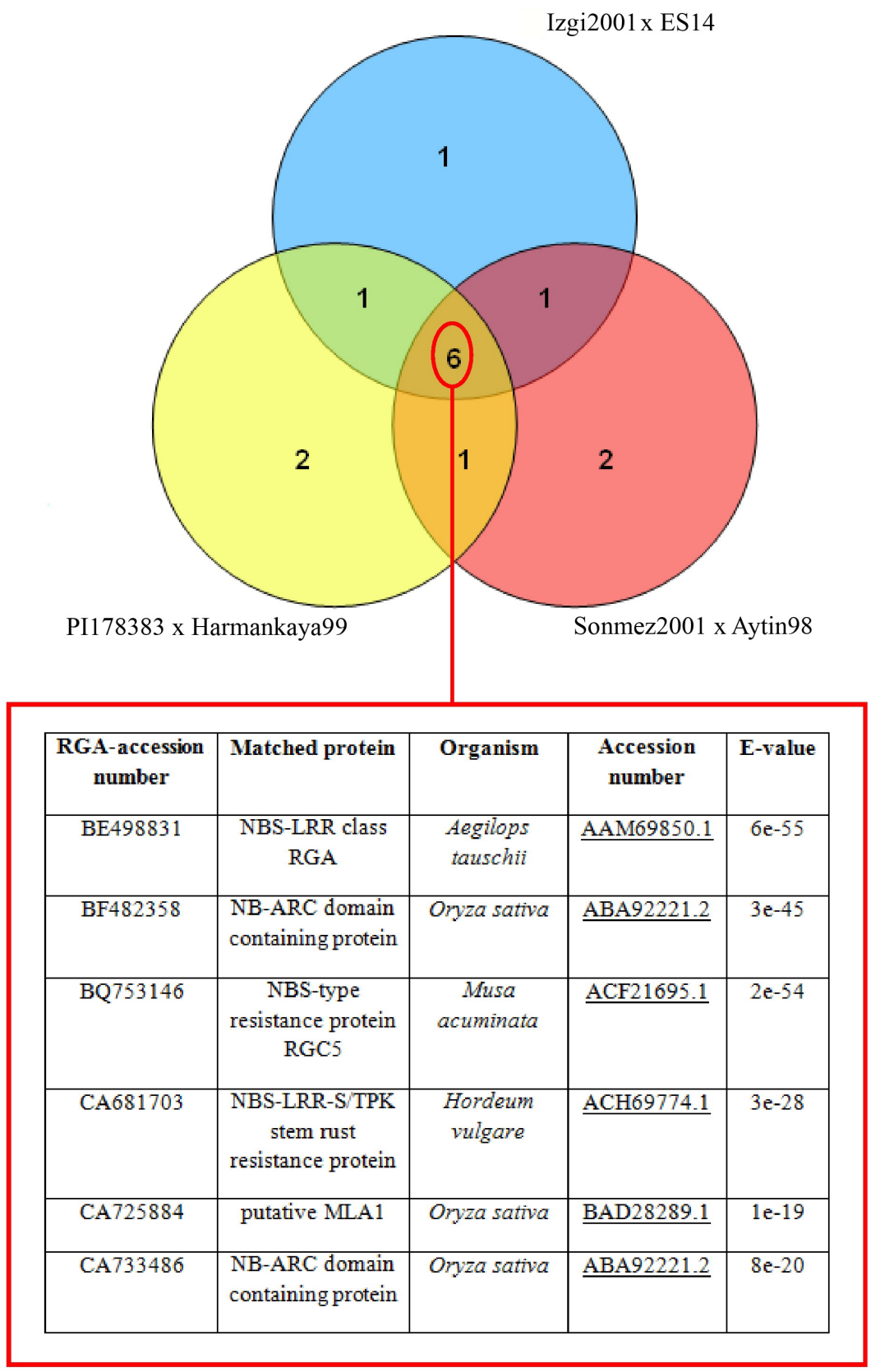

Figure 4. BlastX homologs of resistance gene analog-expressed sequence tag (RGA-EST) sequences, which gave polymorphic patterns for all combinations. 


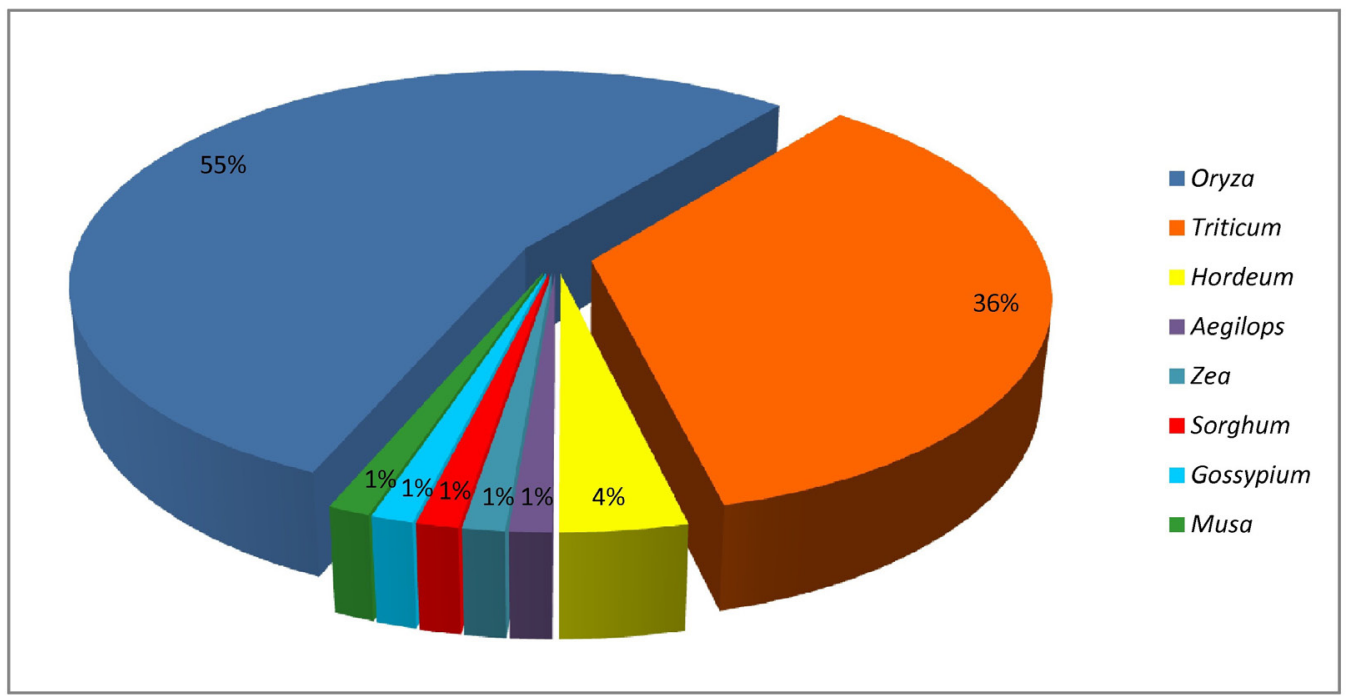

Figure 5. Matched organisms of RGA-EST sequences based on BlastX analyses.

\section{DISCUSSION}

The mapped RGAs provide potentially powerful tools for the development of markers for resistance traits, and for the cloning of NBS-LRR-type resistance genes. This could include genes for broad-spectrum, qualitative disease resistance, because recent studies in different plant species (Wisser et al., 2005; McIntyre et al., 2005) found that in some instances there was a significant association between RGA genes and quantitative resistance traits. In previous studies, several RGAP markers were coincident with resistance to different diseases (Chen et al., 1998, 1999). Shi et al. (2001) identified 16 RGAP markers for the $\mathrm{Yr} 9$ gene resistance to wheat stripe rust, and they determined the presence or absence of the Yr9 gene in cultivars that have been postulated to have Yr9. Similar to these studies, resistant and susceptible wheat genotypes used in this study have already been used for the development of molecular markers for yellow rust resistance by our research group. Along this line, Temel et al. (2008) investigated the sequence differences of yellow rust resistance gene "Yr10" in seven winter-type bread wheat genotypes, and data mining proved that there have been single nucleotide changes especially in the second exon of Yr10. The sequences most similar to the first exon of Harmankaya99, Izgi2001 and Sonmez2001 are AF509535 (Aegilops tauschii NBS-LRR-like gene), AF509534 ( $A$. tauschii NBS-LRR-like gene sequence) and AF509534, respectively. In another study from our group, Akfirat-Senturk et al. (2010) used bulk segregant analysis to identify molecular markers associated with yellow rust disease resistance in Izgi2001 x ES14 cross. This analysis showed that $81 \%$ of the wheat genotypes known to be yellow rust resistant had the SSR marker (Xgwm382). Similar to this, one EST-SSR marker (Pk54) has been identified in a PI178383 x Harmankaya99 cross. It was present in the resistant parent and resistant $\mathrm{F}_{2}$ hybrids but not in the susceptible ones. A total of 108 wheat genotypes differing in yellow rust resistance were screened with $P k 54$, and $68 \%$ of the wheat genotypes, known to be 
yellow rust resistant, showed the presence of Pk54 (Ercan et al., 2010), further suggesting that the presence of these markers correlates with yellow rust resistance in diverse wheat germplasms. Based on the studies mentioned above, RGA-ESTs were used in order to identify genetic diversity between parents and to search for new possible new crosses by using these 6 genotypes for Turkish wheat breeding programs in the frame of this study.

The amount and distribution of genetic diversity within a species must be known if scientific approaches to its conservation and exploitation are to be developed. Methods employing DNA-based markers are currently used to study diversity at the nucleotide level. Among these, PCR-based methods such as RAPD (Williams et al., 1990), AFLP (Vos et al., 1995), and microsatellites (Akkaya et al., 1992) have proven to be useful in many plant species. All of these PCR-based markers have been generated without concern for their function. Given the large size of the wheat genome, these markers mostly reflect variation at non-coding DNA regions. The growing information in databases on plant gene sequences makes it possible to develop universal molecular tools directed at particular targets, i.e., either specific genes or specific genome regions containing clusters of genes with known function. Sequence comparisons among disease resistance genes from different plants have revealed remarkable similarities in their general structure and in the conservation of specific domains that participate in protein-protein interactions and signal transduction (Staskawicz et al., 1995). PCR primers based on conserved peptide motifs have been used to amplify RGA sequences in a large number of plant species (Feuillet et al., 1997; Michelmore, 2000; Pan et al., 2000). It has been reported in different species that about $50 \%$ of the products amplified with primers based on motifs of the NBS domain of several R-genes cannot be considered RGAs (Collins et al., 1998; Fourmann et al., 2001). However, in our study, the BlastX analysis of wheat RGA sequences showed that all wheat RGA sequences were related to R genes. Sicard et al. (1999) explored resistance-gene diversity in cultivated and wild populations of Lactuca using two molecular markers derived from LRR domains, and a microsatellite also present in the main resistance gene cluster in lettuce. These three markers produced similarly high levels of diversity and estimates correlated across populations. Several other studies have reported polymorphism in self-pollinating plants, including rice (22\%) (Maheswaran et al., 1997), sugar beet (50\%) (Schondelmaier et al., 1996) and wild barley (76\%) (Pakniyat et al., 1997).

Our results indicate that EST-derived RGA primers are good tools for assessing genetic diversity in wheat cultivars. A relatively high level of polymorphism $(49.5 \%$ of loci were polymorphic) was observed with 77 RGA primers across the six wheat genotypes, despite the fact that all of them were local cultivars from geographically close locations. In conclusion, RGA-EST sequences can be used to identify suitable parents in population studies designed to detect genes related to disease resistance.

\section{ACKNOWLEDGMENTS}

The authors thank Dr. Necmettin Bolat for providing plant material and Central Research Institute of Field Crops for performing pathogenity tests. This study is part of a $\mathrm{PhD}$ thesis ("Investigation of Yellow Rust Disease Resistance in Winter-Type Bread Wheat - Triticum aestivum L. - Using Biotechnological Methods") by Ozge Karakas performed at the Institute of Sciences and Research Foundation (Project \#1832), Istanbul University. Research supported by TUBITAK KAMAG (Project \#105G075). 


\section{REFERENCES}

Akar T, Yazar S, Donmez E, Avci M, et al. (2007). Current status of national winter wheat breeding in Turkey. J. Agric. Res. 45: 1-9.

Akfirat-Senturk F, Aydin Y, Ertugrul F, Hasancebi S, et al. (2010). A microsatellite marker for yellow rust resistance in wheat. Cereal Res. Comm. 38: 203-210.

Akkaya MS, Bhagwat AA and Cregan PB (1992). Length polymorphisms of simple sequence repeat DNA in soybean. Genetics 132: 1131-1139.

Altintas S, Toklu F, Kafkas S, Kilian B, et al. (2008). Estimating genetic diversity in durum and bread wheat cultivars from Turkey using AFLP and SAMPL markers. Plant Breed. 127: 9-14.

Altschul SF, Gish W, Miller W, Myers EW, et al. (1990). Basic local alignment search tool. J. Mol. Biol. 215: 403-410.

Asif M, Rahman MU and Zafar Y (2005). DNA fingerprinting studies of some wheat (Triticum aestivum L.) genotypes using random amplified polymorphic DNA (RAPD) analysis. Pak. J. Bot. 37: 271-277.

Bennett MD and Leitch IJ (1995). Nuclear DNA amounts in angiosperms. Ann. Bot. 76: 113-176.

Bertini CHCM, Schuster I, Sediyama T, Barros EG, et al. (2006). Characterization and genetic diversity analysis of cotton cultivars using microsatellites. Genet. Mol. Biol. 29: 321-329.

Chen XM, Line RF and Leung H (1998). Genome scanning for resistance-gene analogs in rice, barley, and wheat by highresolution electrophoresis. Theor. Appl. Genet. 97: 345-355.

Chen XM, Line RF, Hayes PM, Toojinda T, et al. (1999). Mapping barley genes for resistance to stripe rust, leaf rust and scab, using resistance gene analog polymorphism and restriction fragment length polymorphism. Phytopathology 89 (Suppl): S15.

Collins NC, Webb CA, Seah S, Ellis JG, et al. (1998). The isolation and mapping of disease resistance gene analogs in maize. Mol. Plant Microbe Interact. 11: 968-978.

Ercan S, Ertugrul F, Aydin Y, Akfirat-Senturk F, et al. (2010). An EST-SSR marker linked with yellow rust resistance in wheat. Biol. Plantarum 54: 691-696.

Feuillet C, Schachermayr G and Keller B (1997). Molecular cloning of a new receptor-like kinase gene encoded at the Lr10 disease resistance locus of wheat. Plant $J .11: 45-52$.

Fourmann M, Chariot F, Froger N, Delourme R, et al. (2001). Expression, mapping, and genetic variability of Brassica napus disease resistance gene analogues. Genome 44: 1083-1099.

Geffroy V, Sicard D, de Oliveira JC, Sevignac M, et al. (1999). Identification of an ancestral resistance gene cluster involved in the coevolution process between Phaseolus vulgaris and its fungal pathogen Colletotrichum lindemuthianum. Mol. Plant Microbe Interact. 12: 774-784.

Gulbitti-Onarici S, Sumer S and Ozcan S (2007). Determination of phylogenetic relationships between some wild wheat species using amplified fragment length polymorphism (AFLP) markers. Bot. J. Linn. Soc. 153: 67-72.

He CY, Tian AG, Zhang JS, Zhang ZY, et al. (2003). Isolation and characterization of a full-length resistance gene homolog from soybean. Theor. Appl. Genet. 106: 786-793.

Jaccard P (1908). Nouvelles recherches sur la distribution florale. Bull. Soc. Vaud. Sci. Nat. 44: 223-270.

Karakas O, Gurel F and Uncuoglu AA (2010). Exploiting a wheat EST database to assess genetic diversity. Genet. Mol. Biol. 33: 719-730.

Kovach WL (1999). MVSP - A Multivariate Statistical Package for Windows, Version 3.1. Kovach Computing Services, Pentraeth.

Maheswaran M, Subudhi PK, Nandi S, Xu JC, et al. (1997). Polymorphism, distribution, and segregation of AFLP markers in a doubled haploid rice population. Theor. Appl. Genet. 94: 39-45.

McFadden HG, Lehmensiek A and Lagudah ES (2006). Resistance gene analogues of wheat: molecular genetic analysis of ESTs. Theor. Appl. Genet. 113: 987-1002.

McIntyre CL, Casu RE, Drenth J, Knight D, et al. (2005). Resistance gene analogues in sugarcane and sorghum and their association with quantitative trait loci for rust resistance. Genome 48: 391-400.

McNeal FM, Conzak CF, Smith EP, Tade WS, et al. (1971). A Uniform System for Recording and Processing Cereal Research Data. USDA Agric. Res. Surv., Washington DC, 34-121.

Michelmore R (2000). Genomic approaches to plant disease resistance. Curr. Opin. Plant Biol. 3: 125-131.

Nagaoka T and Ogihara Y (1997). Applicability of inter-simple sequence repeat polymorphisms in wheat for use as DNA markers in comparison to RFLP and RAPD markers. Theor. Appl. Genet. 94: 597-602.

Pakniyat H, Powell W, Baird E, Handley LL, et al. (1997). AFLP variation in wild barley (Hordeum spontaneum C. Koch) with reference to salt tolerance and associated ecogeography. Genome 40: 332-341.

Pan Q, Wendel J and Fluhr R (2000). Divergent evolution of plant NBS-LRR resistance gene homologues in dicot and 
cereal genomes. J. Mol. Evol. 50: 203-213.

Plaschke J, Ganal MW and Röder MS (1995). Detection of genetic diversity in closely related bread wheat using microsatellite markers. Theor. Appl. Genet. 91: 1001-1007.

Qin GJ, Chen PD, Gu HY, Feng YG, et al. (2003). Isolation of resistance gene analogs from wheat based on conserved domains of resistance genes. Acta Bot. Sin. 45: 340-345.

Schondelmaier J, Steinrücken G and Jung C (1996). Integration of AFLP markers into a linkage map of sugar beet (Beta vulgaris L.). Plant Breed. 115: 231-237.

Shi ZX, Chen XM, Line RF, Leung H, et al. (2001). Development of resistance gene analog polymorphism markers for the Yr9 gene resistance to wheat stripe rust. Genome 44: 509-516.

Sicard D, Woo SS, Arroyo-Garcia R, Ochoa O, et al. (1999). Molecular diversity at the major cluster of disease resistance genes in cultivated and wild Lactuca spp. Theor. Appl. Genet. 99: 405-418.

Song W and Henry RJ (1995). Molecular analysis of the DNA polymorphism of wild barley (Hordeum spontaneum) germplasm using the polymerase chain reaction. Genet. Resourc. Crop Evol. 42: 273-280.

Staskawicz BJ, Ausubel FM, Baker BJ, Ellis JG, et al. (1995). Molecular genetics of plant disease resistance. Science 268: 661-667.

Temel A, Senturk-Akfirat F, Ertugrul F, Yumurtaci A, et al. (2008). Yr10 gene polymorphism in bread wheat varieties. Afr. J. Biotechnol. 7: 2328-2332.

Vos P, Hogers R, Bleeker M, Reijans M, et al. (1995). AFLP: a new technique for DNA fingerprinting. Nucleic Acids Res. 23: 4407-4414.

Weining S and Langridge P (1991). Identification and mapping of polymorphisms in cereals based on the polymerase chain reaction. Theor. Appl. Genet. 82: 209-216.

Williams JG, Kubelik AR, Livak KJ, Rafalski JA, et al. (1990). DNA polymorphisms amplified by arbitrary primers are useful as genetic markers. Nucleic Acids Res. 18: 6531-6535.

Wisser RJ, Sun Q, Hulbert SH, Kresovich S, et al. (2005). Identification and characterization of regions of the rice genome associated with broad-spectrum, quantitative disease resistance. Genetics 169: 2277-2293.

Yan GP, Chen XM, Line RF and Wellings CR (2003). Resistance gene-analog polymorphism markers co-segregating with the YR5 gene for resistance to wheat stripe rust. Theor. Appl. Genet. 106: 636-643. 